\title{
The Effect of Induced Acid Rain; Allium cepa Chromosomal Aberration
}

\section{Assay}

Renjith Raju $^{1 *}$, Allwin George Paul ${ }^{1}$, Unnis P. Aguilor ${ }^{1}$, Julius T. Capili ${ }^{1}$

${ }^{1}$ Cagayan State University, Tuguegarao City, Cagayan, Philippines

DOI: $10.36347 /$ sajb.2021.v09i03.005

| Received: 28.02.2021 | Accepted: 18.03.2021 | Published: 23.03.2021

*Corresponding author: Renjith Raju

Abstract

Original Research Article

Since there is insufficient study about morphological and genetic alteration of acid rain using Allium cepa test; hence, this study was conducted. Sulfuric acid $\left(\mathrm{H}_{2} \mathrm{SO}_{4}\right)$ was used to simulate acid rain. The two parameters were observed in six (6) treatments where in $\mathrm{T} 1$, served as negative control (distilled water at $\mathrm{pH} 7$ ), followed by varying $\mathrm{pH}$ values of simulated sulfuric acid rain - T2 (pH 3.8), T3 (pH 4.08), T4 (pH 4.4), T5 (pH 4.63) and T6 (pH 5.32). To evaluate the morphological effects simulated sulfuric acid rain, number of root counts, percentage root growth and root length were considered. On the other, mitotic index, chromosomal index and chromosomal aberration were the focused of genetic alteration of simulated sulfuric acid rain. Thus, T1, as negative control, showed higher percentage root growth, longer root lengths, higher MI value and lower CI value, as compared to the rest of the treatments. On the other hand, T3 (using $\mathrm{pH}$ value of 4.08) had the lowest number of roots grown. T2 (using $\mathrm{pH}$ value of 3.80) showed lowest percentage root growth, shortest roots lengths, lowest MI value and highest CI value, as compared to the rest of the treatments. Moreover, there were nine (9) chromosomal aberration identified. And all of these were observed in T2. These CAs include sticky, laggard, bridge, and vagrant chromosomes, micronucleus, fragments, polyploidy, binucleate and nuclear lesions. But in T7, having the lowest frequency of aberrant cell, only sticky and vagrant chromosomes, fragments and polyploidy were the chromosomal aberrations observed in this treatment. It can be concluded that low $\mathrm{pH}$ values of simulated sulfuric acid did interfere with cell division and has genotoxicity effect on the cells as indicated by the morphological facet of the $A$. серa roots. Thus, these results suggest that the lower $\mathrm{pH}$ value of simulated sulfuric acid rain, the more adverse morphological and genetic alteration effect to $A$. серa.

Keywords: acid rain, sulfuric acid, Allium серa, chromosomal aberration, genetic alteration, genotoxicity.

Copyright $\left({ }_{0} 2021\right.$ The Author(s): This is an open-access article distributed under the terms of the Creative Commons Attribution 4.0 International License (CC BY-NC 4.0) which permits unrestricted use, distribution, and reproduction in any medium for non-commercial use provided the original author and source are credited.

\section{INTRODUCTION}

Acid deposition is any form of precipitation with acidic components such as sulfuric and nitric acid that falls to the ground which comes from the atmosphere in wet or dry form. It may occur it the form of rain, fog, sleet or snow. Hence, this study focused mainly on the most common wet form of acid deposition which is the rain. Acid rain is formed when gases such as carbon dioxide, sulfur dioxide and nitrogen oxide are present in the atmosphere. If these gases - Carbon dioxide $\left(\mathrm{CO}_{2}\right)$, Sulfur dioxide $\left(\mathrm{SO}_{2}\right)$ and Nitrogen dioxide $\left(\mathrm{NO}_{2}\right)$ dissolved in water; each of these are hydrolyzed to become carbonic acid, sulfuric acid and nitric acid, types of weak and strong acid, respectively, which now provide a major source of acid rain. In relation to the present atmospheric conditions, the atmosphere thus consists of many types of contaminants mainly the previously mentioned gases. The source of these gases is mainly from natural activities almost all caused by anthropogenic activities. These activities include excessive emission of waste gases automobiles, power generations' facilities, factories, industries, burning of fossil fuels also deforestation. With this intense urbanization and industrialization, there will be increase on the levels of $\mathrm{CO}_{2}, \mathrm{SO}_{2}$ and $\mathrm{NO}_{2}$ in the atmosphere and when it rains; the rainwater is expected to be acidic. Normal rainwater is slightly acidic with a $\mathrm{pH}$ range of 5.3-6.0. The range of $\mathrm{pH}$ value of acid rain is lower than normal rainwater.

When these acidic rains fall off to the ground, with bioaccumulation and biomagnification, there will come a time that these can contribute to variety of toxic effects on living organisms in food chain. Moreover, acid precipitation has been identified as a major environmental concern in developing countries like Canada, Japan, and United states and somewhere in northern European countries. In the Philippines, on the other hand, is free from acid rain incident. 
However, the soil as traditionally the receiver of the acidic rainwater and it is where the plants grow is assumed that plants have a direct hit from this kind of pollution. With this premise, the researcher sought to study the effect of acid rain to plants particularly on the mitotic activity and chromosomal behavior of plants' root meristems using Allium cepa test by which the onion was treated with sulfuric acid, a simulated form of acid rain.

\section{MATERIALS AND METHODS}

Small bulbs ranging $1.5-2.0 \mathrm{~cm}$ in diameter of the common onion, A cepa, were purchased at Don Domingo Public Market. The identification of the onion was authenticated at the Department of Agriculture Regional field Office. The materials used by the researchers in the study are petri dish, cotton, forceps or sharp blade, graduated cylinder, pipette, aspirator, test tubes, filter paper, reagent bottle, beaker, hot plate, spatula, water bath, cheese cloth, Vernier caliper, glass slides, cover slips, dropper, microscope, ventilated oven, blender, plastic container, $\mathrm{pH}$ meter, lighter, universal indicator, sulfur powder, sodium bicarbonate $\left(\mathrm{NaHCO}_{3}\right)$, incubator, modified acid rain and roots of Allium cepa. The reagents utilized are Carnoy's solution, absolute ethyl alcohol, chloroform, glacial acetic acid, $1 \mathrm{~N} \mathrm{HCl,}$ acetocarmine, 1 gram carmine dye and distilled water.

\section{Preparation of Acid Rain}

A teaspoon of sulfur powder that was burnt with the help of lighter was added to a $100 \mathrm{~mL}$ of distilled water placed on a beaker with a little amount of universal indicator. After the preparation, sulfurous acid was formed. Due to the formation of the sulfurous acid, the color of the solution changed to red. The change of color of the solution means the solution became acidic. The varying solutions of known $\mathrm{pH}$ were prepared by adding different concentrations of soda $\left(\mathrm{NaHCO}_{3}\right)$ and the $\mathrm{pH}$ level was validated using the $\mathrm{pH}$ meter. The results were pH 3.8, pH4, pH 4.4, pH 4.6.

\section{Treatment and Bulb's Root Germination}

Prior to initiating the test, we removed the outer scales and the dry bottom of the bulb without destroying the root primordia. For each treatment, we placed a series of 5 bulbs in a distilled water ( $\mathrm{pH} 7)$, modified acid rain of different $\mathrm{pH}$ values, $\mathrm{pH} 3.8, \mathrm{pH} 4, \mathrm{pH} 4.4, \mathrm{pH} 4.6$ for treatments, T2, T3 T4 and T5 respectively for about 48 hours. The test samples were changed daily at the same time. The bulbs with satisfactory root lengths ranging 2$2.5 \mathrm{~cm}$ was used in the study, while those with exceptionally long or short roots were discarded. After 48 hours of exposure, several root tips were removed from the bulbs, fixed in Carnoy's solution and stored over night at $4^{\circ} \mathrm{C}$. An average of two slides were made for each bulb using four root tips ( 2 per slide) which were hydrolyzed in $1 \mathrm{~N}$ hydrochloric acid $(\mathrm{HCl})$ for $3 \mathrm{mins}$ and microscope slides were prepared by the squashing technique.
Preparation of Carnoy's Solution, Reagents and Acetocarmine Stain

1. Carnoy's solution

Carnoy's solution was used to fix and store the root tips. The solution was prepared by mixing the six parts of absolute ethyl alcohol, three parts of chloroform and one part of glacial acetic acid and stored in a reagent bottle.

\section{N Hydrochloric Acid}

To prepare $1 \mathrm{~N} \mathrm{HCl} 100 \mathrm{~mL}$ solution, $15 \mathrm{~mL}$ of $\mathrm{HCl}$ were added with $85 \mathrm{ml}$ of distilled water. The purpose of $\mathrm{HCl}$ was to break the cell wall to facilitate absorption of the stain through the cell membrane to the nucleus of the cell.

\section{Acetocarmine Stain}

The stain was prepared by mixing $1 \mathrm{~g}$ carmine dye and $100 \mathrm{~mL}$ glacial acetic acid which was boiled for 5-10 minutes. After it has subsequently cooled, the solution was filtered and stored in a reagent bottle. Acetocarmine stain was used to stain the chromosomes.

\section{Squashed Technique for Mitotic Chromosomes}

The root tips were transferred from the Carnoy's fixative solution using a pair of forceps into a clean glass slide. The solution has several purposes; it preserves the cell morphology, acts as a disinfectant and permits better staining reaction. Using sharp blades or forceps, about $1 \mathrm{~mm}$ of the terminal end of the root tip was cut and discarded. The remaining parts were washed with distilled water and drained. A drop of $1 \mathrm{~N} \mathrm{HC1} \mathrm{was}$ applied on the root sample and allowed to stand for 3 minutes after which it was drained. The purpose of $\mathrm{HC} 1$ was to break the cell wall to facilitate absorption of the stain by the cells. Then a drop of acetocarmine was placed on the root tip and then allowed to stand for 15 minutes. A cover slip was placed on the slide to cover the root tip. Using the thumb to keep the slide in place, a pencil eraser was used to evenly press the root tips by gently tapping it on the cover slip. Then the smear was examined under the oil immersion objective (100X) for mitotic index and cytogenetic analysis. A digital Samsung camera was used to document the field views.

\section{Determination of Genotoxicity 1. Root length $(\mathrm{cm})$}

With the help of vernier caliper root length was measured, and were calculated by using the root mean length $(\mathrm{cm})$ following this equation: \% of root growth control $=$ mean root length/overall number of roots $\times 100$

\section{Determination of mitotic index}

Cells in ten (10) fields for each treatment in each replicate were observed to determine mitotic index. This was computed using the following formula:

Mitotic Index $=$ number of dividing cells/total number of cells observed $\times 100$ 


\section{Determination of Chromosomal Aberrations}

Cells in each treatment were evaluated for chromosomal aberrations. Changes in chromosome structure, such as gaps, breakages, loose sister chromatids, will be scored. Further, behaviors of chromosomes during were also observed. The presence of laggards, bridges, c-mitosis, delayed anaphase and other aberrations were identified. Other cytogenetic abnormalities were also scored.

\section{RESULTS AND DISCUSSION}

This study reveals the morphological and genetic alteration effect of varying $\mathrm{pH}$ values of simulated sulfuric acid rain by using Allium cepa test. The parameters considered in this study are as follows: (a.) macroscopic analysis (morphological) which includes root number and root length and (b) microscopic analysis (genetic alterations) which includes mitotic index, chromosomal aberration and aberration index.

\section{MACROSCOPIC INDEX}

A total of 30 onion bulbs, of the purple variety, of the same average sizes, were soaked in distilled water and in varying $\mathrm{pH}$ values of simulated sulfuric acid rain for one week. With this set-up, root growth and root length were evaluated.

Root growth is accounted for the result that describes the number of bulbs among the treatments that would be naturally slow or poor growing [2]. This was indicated by low root counts grown from each of the bulbs per treatments.

Results of analysis of variance, in the number of roots, revealed significant difference at $1 \%$ level (highly significant) among treatments with observe $F$ value of 5.67 greater than tabular F value of 3.90. Further analysis using DMRT test revealed that Treatment 1 (using distilled water) is significantly different at $1 \%$ level as compared to Treatment 6 (using $\mathrm{pH}$ of 5.32), but not significantly different compared to $\mathrm{T} 5$ (using $\mathrm{pH}$ of 4.63) $\mathrm{T} 4$ (using $\mathrm{pH}$ of 4.40), $\mathrm{T} 3$ (using $\mathrm{pH}$ of 4.08) and $\mathrm{T} 2$ (using $\mathrm{pH}$ of 3.80). Treatment 6 was found not significantly different to T5, T4, T3 and T2. Hence, low $\mathrm{pH}$ values thus affect the number of roots grown in each onion bulb per treatment.

Table-1: DMRT analysis shows the summary of means for the number of roots grown distilled water and in different $\mathbf{p H}$ values of simulated

\begin{tabular}{|l|l|l|l|}
\hline \multicolumn{4}{|l|}{ NUMBER OF ROOTS } \\
\hline DMRT & Treatment Mean & Statistical Significance & Rank \\
\hline Treatment & $\mathbf{1 1 . 0 0}$ & A & 1 \\
\hline T1-pH of 7.00 (distilled water) & $\mathbf{4 . 0 0}$ & $\mathbf{C}$ & 5 \\
\hline T2-pH of 3.80 & $\mathbf{3 . 6 0}$ & $\mathbf{C}$ & 6 \\
\hline T3-pH of 4.08 & $\mathbf{5 . 4 0}$ & $\mathbf{C}$ & 4 \\
\hline T4- pH of 4.40 & $\mathbf{5 . 6 0}$ & C & 3 \\
\hline T5- pH of 4.63 & $\mathbf{6 . 6 0}$ & Bc & 2 \\
\hline T6- pH of 5.32 &
\end{tabular}

Note: Any two means having a common letter are not significantly different at $5 \%$ level. Bold face means significantly different at $1 \%$ level to the preceding letter.

Moreover, low number of root growth in treatments ( $\mathrm{T} 2$ and $\mathrm{T} 3$ ) with low $\mathrm{pH}$ was also accompanied by decreased in root length as compared to Treatment 1 (using distilled water). Root length is evaluated by measuring all the roots grown in each bulb per treatment. The results of the number of roots are related with the root length because the optimum range for $\mathrm{pH}$ of soil is 5.5-7.00 [3].

Results of analysis of variance, in root length, revealed significant difference at $1 \%$ level (highly significant) among treatments with observe $F$ value of 5.67 greater than tabular $F$ value of 3.90. Further analysis using DMRT test revealed that Treatment 1 (using distilled water) is not significantly different at $1 \%$ level as compared to Treatment 6 (using $\mathrm{pH}$ of 5.32), but significantly different at 5\% level compared to T5 (using $\mathrm{pH}$ of 4.63) and significantly different $1 \%$ level compared to $\mathrm{T} 4$ (using $\mathrm{pH}$ of 4.40 ), $\mathrm{T} 3$ (using $\mathrm{pH}$ of 4.08) and T2 (using pH of 3.08). Treatment 6 was found not significant compared to T5 but significantly different at $1 \%$ compared to $\mathrm{T} 4, \mathrm{~T} 3$ and $\mathrm{T} 2$. Treatment 5 was found not significant compared to $\mathrm{T} 4$ and significantly different by $1 \%$ level compared to T3 and T2. Treatment 4 was significantly different by $1 \%$ compared to $\mathrm{T} 3$ and $\mathrm{T} 3$ is not significantly different compared to T2. Hence, the lower the $\mathrm{pH}$ value, the shorter the length of roots. 
Table-2: DMRT analysis shows the summary of means for length $(\mathrm{cm})$ of roots grown in distilled water and in different $\mathrm{pH}$ values of simulated acid rain for one week

\begin{tabular}{|l|l|l|l|}
\hline \multicolumn{2}{|l|}{ ROOT LENGHT (cm) } \\
\hline DMRT & Treatment Mean & Statistical Significance & Rank \\
\hline Treatment & $\mathbf{5 . 9 5}$ & A & 1 \\
\hline T1-pH of 7.00 (distilled water) & $\mathbf{1 . 3 2}$ & E & 6 \\
\hline T2-pH of 3.80 & $\mathbf{1 . 9 7}$ & De & 5 \\
\hline T3-pH of 4.08 & $\mathbf{3 . 4 3}$ & C & 4 \\
\hline T4- pH of 4.40 & $\mathbf{4 . 4 3}$ & Bc & 3 \\
\hline T5- pH of 4.63 & $\mathbf{5 . 1 8}$ & Ab & 2 \\
\hline T6- pH of 5.32 & &
\end{tabular}

Note: Any two means having a common letter are not significantly different at $5 \%$ level.

Bold face means significantly different at $1 \%$ level to the preceding letter.

Generally, in low $\mathrm{pH}$ values, inhibition of rooting (low root counts and low percentage root growth) and the appearance of stunted roots (shorter root length) were very obvious. These observations indicate there is retardation of growth and cytotoxicity. Retardation of root growth and cytotoxicity imply inhibition of mitotic activity and occurrence of chromosomal aberration [4]. Hence, results obtained from the determining the root growth and root length can be used to correlate the results that will be obtained from the two (2) more microscopic parameters namely mitotic index (MI) and aberration index (AI).

Moreover, T2 which had the lowest $\mathrm{pH}$ of 3.80 is considered to have adverse effects on plants. T2 showed inhibition of root growth and accompanied by short root lengths. And, it is suspected also to have low MI and AI, respectively. Therefore, if in any case real acid rain will occur, the $\mathrm{pH}$ of 3.80 could already harm the plants.

\section{MICROSCOPIC ANALYSIS}

Among the roots grown in the five (5) onion bulbs per treatment, researchers randomly chose five root tips where the ten (10) different field of views (HPO, 400x) were observed. The later was used where to locate, identify and count the cells undergoing interphase $(\mathrm{I})$, prophase $(\mathrm{P})$, metaphase $(\mathrm{M})$, anaphase $(\mathrm{A})$ and telophase (T) and used where to observe and identify chromosomal aberrations to compute $\mathrm{MI}$ and $\mathrm{CI}$, respectively.

\section{MITOTIC INDEX}

The cytotoxic level of a test chemical/compound can be determined based on the increase or decrease in MI. So, MI is used as a parameter of cytotoxicity in environmental biomonitoring studies [1].

In relation to the present study, the cytotoxic level of sulfuric acid, or simulated sulfuric acid rain, at varying $\mathrm{pH}$ values, and distilled water were determined by computing the MI. Hence, it was observed that there is significant reduction in MI (3.2771) noted in Treatment 2 ( $\mathrm{pH}$ of 3.80); as expected from the result of root growth and root length. However, in Treatment 1 (distilled water) showed the highest MI (10.642).

So, the observed suppression of mitotic activity implies a trace of cytotoxic level of simulated sulfuric acid rain. In relation to the study, a $22 \%$ (or below 22\%) decrease in mitotic index as compared to the negative control (distilled water) causes lethal effects on test organism while a decrease below $50 \%$ has sub lethal effects and is called cytotoxic limit value [1].

Table-3: Comparison of the Treatments in the Decline of MI values

\begin{tabular}{|l|l|l|l|}
\hline TREATMENT & MI & PERCENTAGE DECLINE (\%) & REMARKS \\
\hline T1-pH of 7.00 (distilled water) & 10.6424 & ---- & ---- \\
\hline T2-pH of 3.80 & 3.2771 & 30.79 & SUB LETHAL \\
\hline T3-pH of 4.08 & 4.2399 & 39.83 & SUB LETHAL \\
\hline T4- $\mathrm{pH}$ of 4.40 & 7.0450 & 66.20 & $* * *$ non-lethal \\
\hline T5- $\mathrm{pH}$ of 4.63 & 5.7941 & 54.44 & $* * *$ non-lethal \\
\hline T6- $\mathrm{pH}$ of 5.32 & 8.4695 & 79.58 & $* * *$ non-lethal \\
\hline
\end{tabular}

Table-3 shows the comparison of the treatments in the decline of MI values. With, T1 (using distilled water at $\mathrm{pH} 7.00)$, as basis for comparing the decline in MI\% of 10.6424 , Treatment 2 (pH of 3.80) with a percentage decline of $30.79 \%$ was considered sub-lethal,
Treatment 3 (4.08) with a percentage decline of 39.83 was considered sub-lethal, while the remaining treatments (T4, T5, T6) were considered non-lethal. Hence, the sub-lethal effect of the decline of MI in T2 
and T3 was indicated by low percentage rate of root growth (Figure-1) and stunted roots (Table-2).

Reduction in MI is due to the inhibition of DNA synthesis or the blocking in the G2 phase of the cell cycle, thus, preventing the cells to proceed mitosis [1]. Hence, in relation to this present study, significant reduction in $\mathrm{MI}$ was observed in $\mathrm{T} 1$ and $\mathrm{T} 2$ by which these treatments have significantly low $\mathrm{pH}$ levels. So, this result implies that low $\mathrm{pH}$ levels (3.08-4.08) may have inhibitory effect in the cell division of A. cepa; thus, this may be responsible for the reduction of PMAT counts which result to low MI values of T2 and T3.

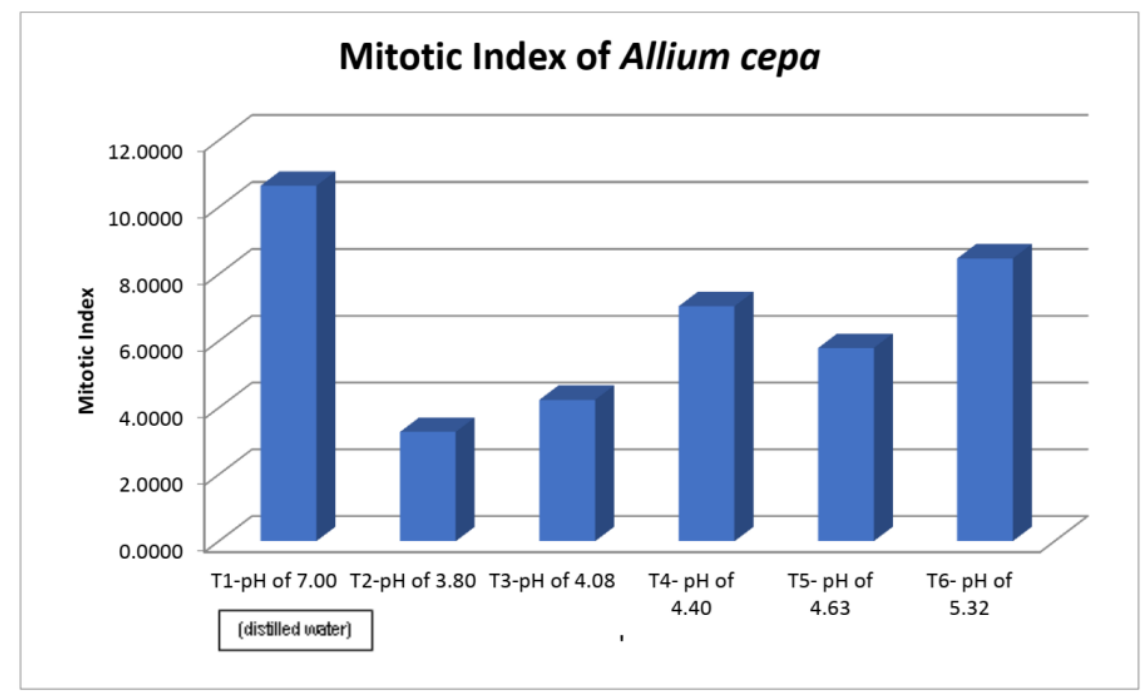

Fig-2: This shows the mitotic index of A. cepa each treatment

Figure-3 shows the various cells undergoing different stages of cell division - interphase (Fig-3a), prophase (Fig-3b), metaphase (Fig-4c), anaphase (Fig-5d) and telophase (Fig-5e).

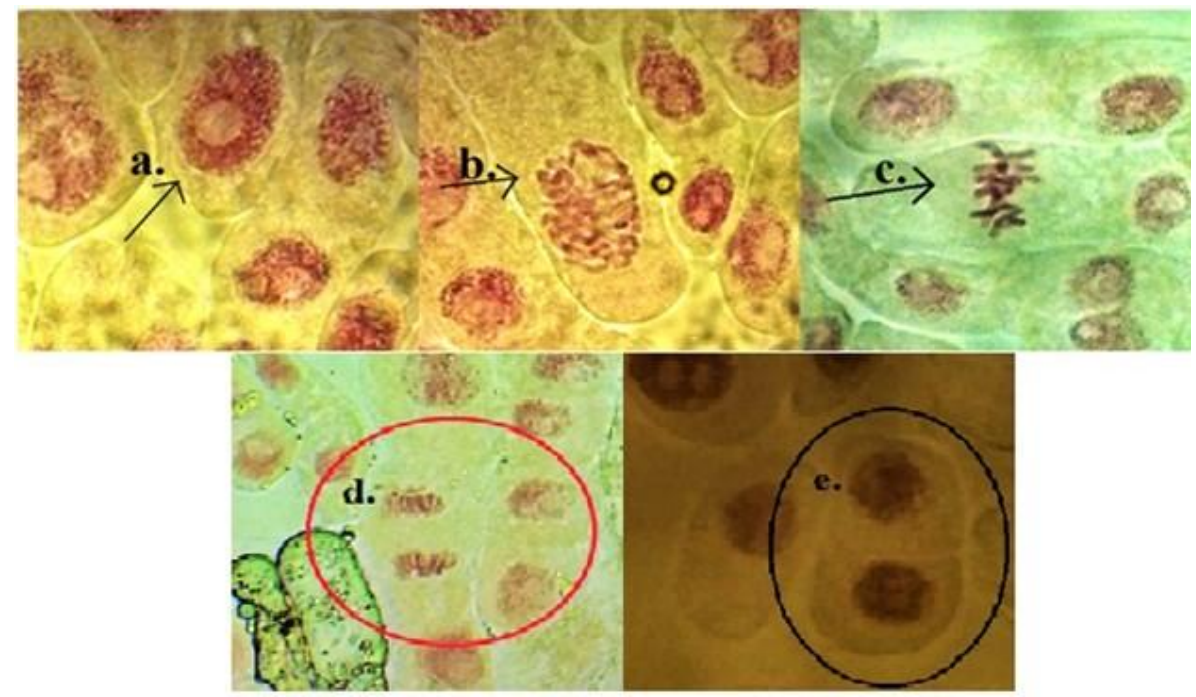

Fig-3: Photograph of normal phases of mitotic cell of A. cepa observed in T1 (distilled water). a. cell undergoing interphase (with visible nucleus); b. cell undergoing prophase (the chromosomes supercoil, no nuclear membrane present); c. cell undergoing metaphase (chromosomes are found along the center plane of the cell); $\mathbf{d}$. cell undergoing anaphase (sister chromatids are in opposite poles) and e. cell undergoing telophase (when, cytokinesis

\section{CHROMOSOMAL ABERRATIONS (CA)}

CAs are characterized by change in either total number of chromosomes or in chromosomal structures which occur as a result of exposure to a certain chemical treatment [1]. Some CAs are lethal. Some are related to aberration that are viable and can cause genetic effects either somatic or inherited. Moreover, these CAs are group into two types - clastogenic and physiological [1].
In this study, a total of nine (9) CAs were observed and identified. These include the nuclear lesions, chromosomal bridges and fragments, binucleated nucleus, vagrant chromosomes, micronucleus, laggard chromosome, polyploidy and sticky chromosome, and were arranged chronologically, in manner which CA were most frequently observed (Table-4). 
With this result, it somehow implies that $\mathrm{pH}$ values of simulated sulfuric acid rain do not only interfere with cell division, but also affect chromatin organization or DNA replication causing change in either total number of chromosomes or in chromosomal structures. Hence, frequencies of total number of chromosomal aberrations increased significantly as the roots were exposed to lower $\mathrm{pH}$ values of simulated sulfuric acid rain (Figure-4).

Moreover, the most occurring CA was nuclear lesions (Figure 7H). This chromosomal aberration is most likely observed in interphase and prophase. This was indicated by a disturbed nucleus by which contents of it do not adhere in contact forming a lesion in the nucleus.

Moreover, chromosomal bridges seen Figure 5B) and fragments seen Figure 5A, Figure 5B are clastogenic CAs observed in this study. These bridges and fragments are clastogenic effects or both of them resulted from chromosome and chromatid breaks, deletion, addition or rearrangement. With this, bridges and breaks may lead to loss and change of genetic material or structural chromosome mutations. Hence, this result implies that low $\mathrm{pH}$ of simulated sulfuric acid rain is a potent clastogen.

The presence of binucleated cells seen Figure 5C was also noted in this study. The occurrence of binucleated cells was the result of inhibition of cytokinesis process of cell division. Thus, low $\mathrm{pH}$ of simulated sulfuric acid rain can inhibit cytokinesis.

On the other hand, the physiological CAs observed in this study include vagrants seen in Figure $6 \mathrm{D}$, laggards seen in Figure 5B and stickiness seen in Figure 7G. Vagrants, laggards and sticky chromosomes had been correlated to the failure of the chromosomes to get attached to the spindle fiber and to move either of the two poles that results in the scattering of the over the cells [1]. A vagrant chromosome is a chromosome moves ahead of from its chromosomal group toward poles [1]. Laggards may be attributed on the failure of spindle apparatus to organize in a normal way. Hence, both these two CAs can result to the unequal separation of number of chromosomes in the daughter cells, which can lead polyploidy and aneuploidy. Polyploidy seen in Figure $6 \mathrm{~F}$, on the other hand, was observed also in this study.

Stickiness is also due to the inhibition of spindle formation. If there is improper folding of chromosomes fibers chromatids connected by sub chromatid bridges lead to form sticky chromosomes that may cause incomplete separation of daughter chromosomes. Chromosome stickiness reflects toxic effects, usually of an irreversible type and probably leading to cell death [1]. Thus, the presence of sticky chromosomes suggests the toxicity of test chemical used in this study - low varying $\mathrm{pH}$ of simulated sulfuric acid rain. Cells bearing micronucleus (Figure 6E) were observed at interphase and prophase stages. Reported in their study that the presence of micronuclei can be spontaneously originated due to the development of the isolated chromosome that results from an unequal distribution of genetic material [1]. According to some authors, this aberration can be a formed as a result from acentric fragments or entire chromosomes not incorporated to the main nucleus during the cell cycle. Therefore, the chemical used in this study, simulated sulfuric acid rain, at different $\mathrm{pH}$ levels were able to promote micronuclei formation; hence, it has clastogenic activity.

\section{B.3. CHROMOSOMAL INDEX (AI)}

Figure-4 shows the aberration index of each treatments, where in the AI was observed in Treatment 2 (3.30). Therefore, the lower the $\mathrm{pH}$ value, the higher clastogenic activity, thus, higher number of chromosomal aberrations. This result implies the genotoxicity effect of low $\mathrm{pH}$ value of simulated sulfuric acid rain.

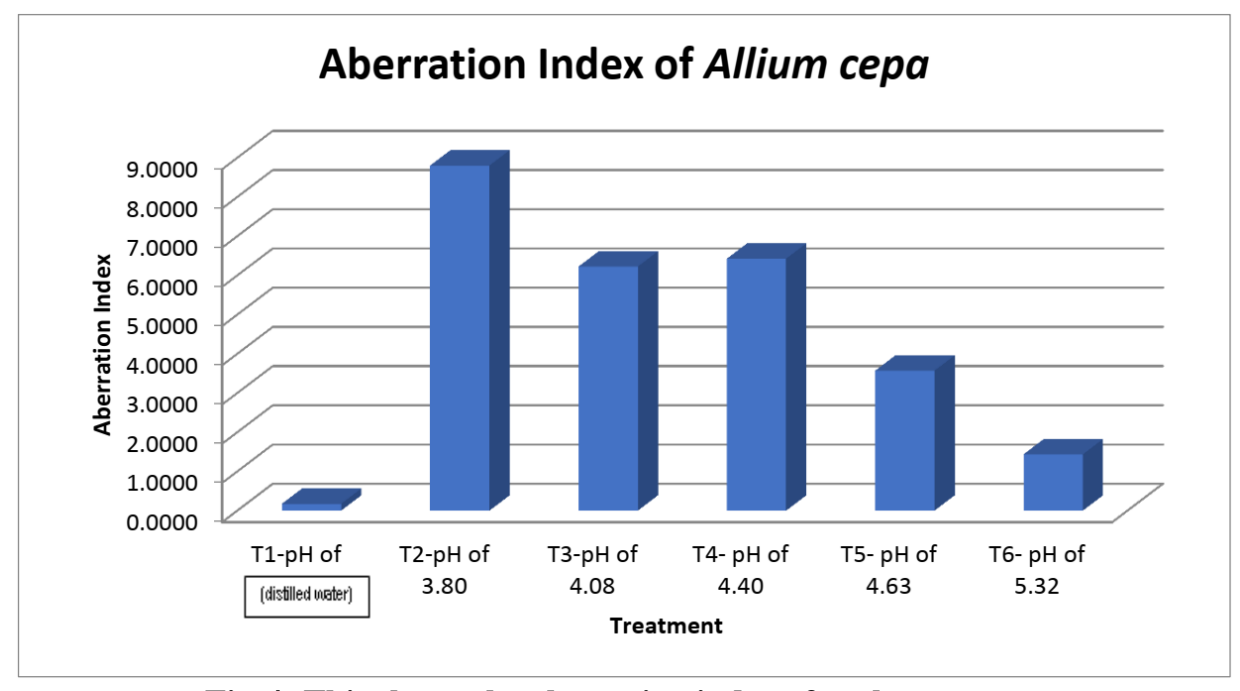

Fig-4: This shows the aberration index of each treatment 


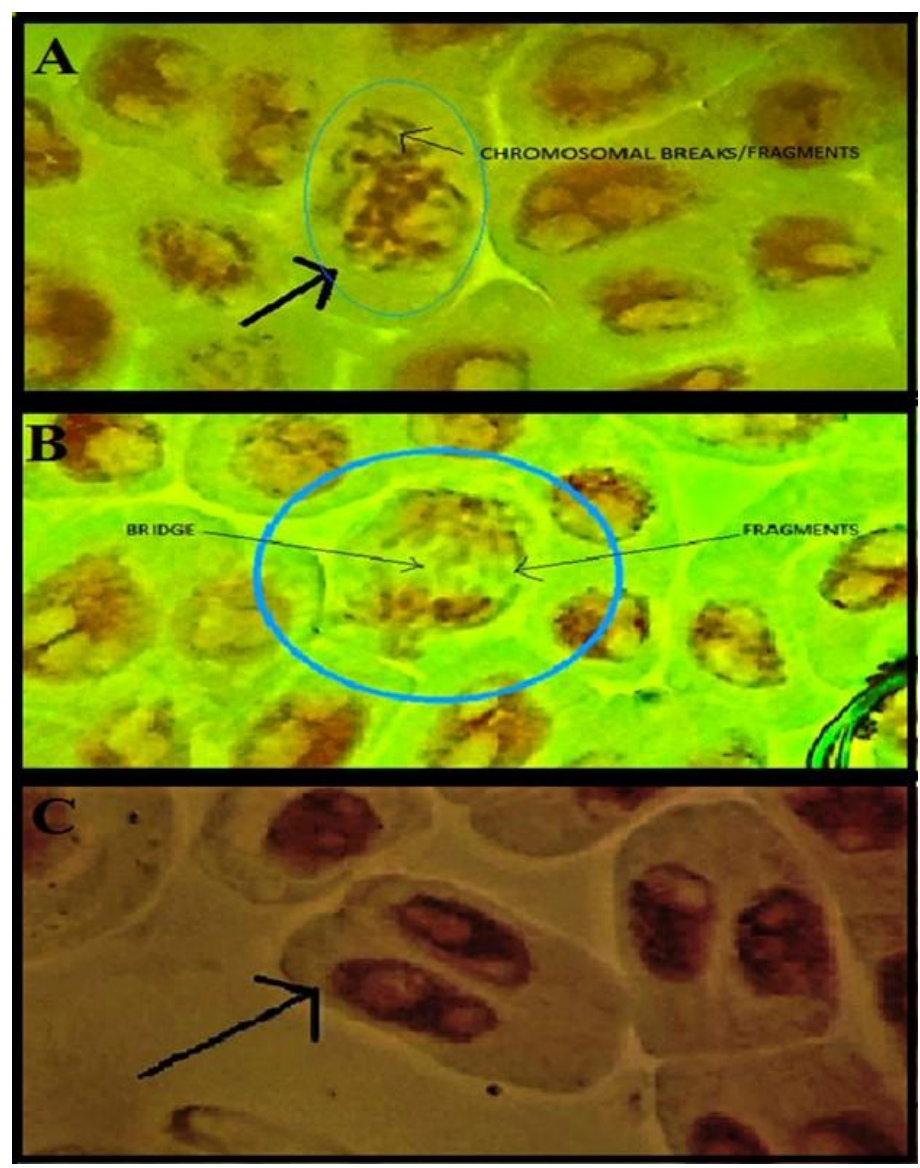

Fig-5: This shows chromosomal aberrations (A) chromosomal breaks/fragments (B) bridge + fragments + laggard chromosome and $(\mathrm{C})$ binucleated cell

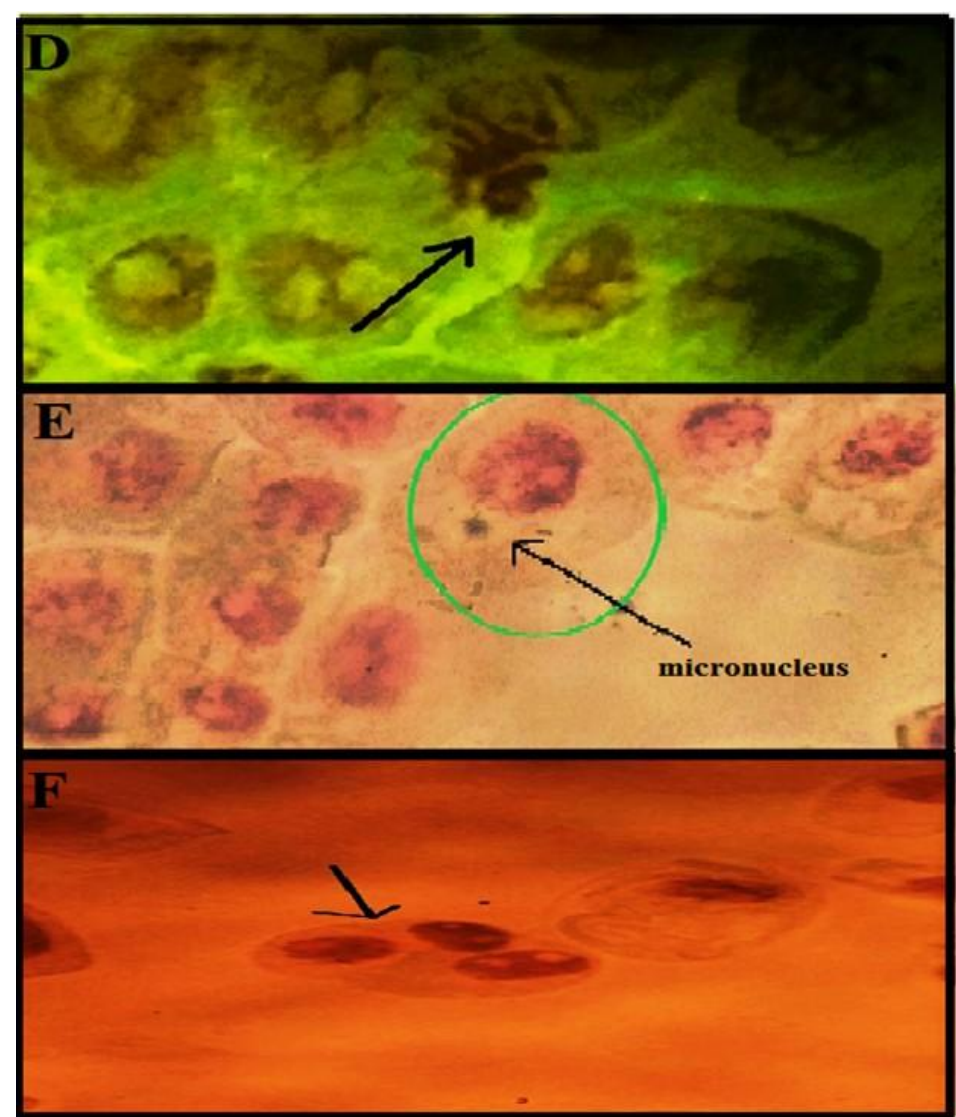

Fig-6: This shows chromosomal aberrations (D) vagrant chromosome (E) micronucleus and (F) polyploidy 


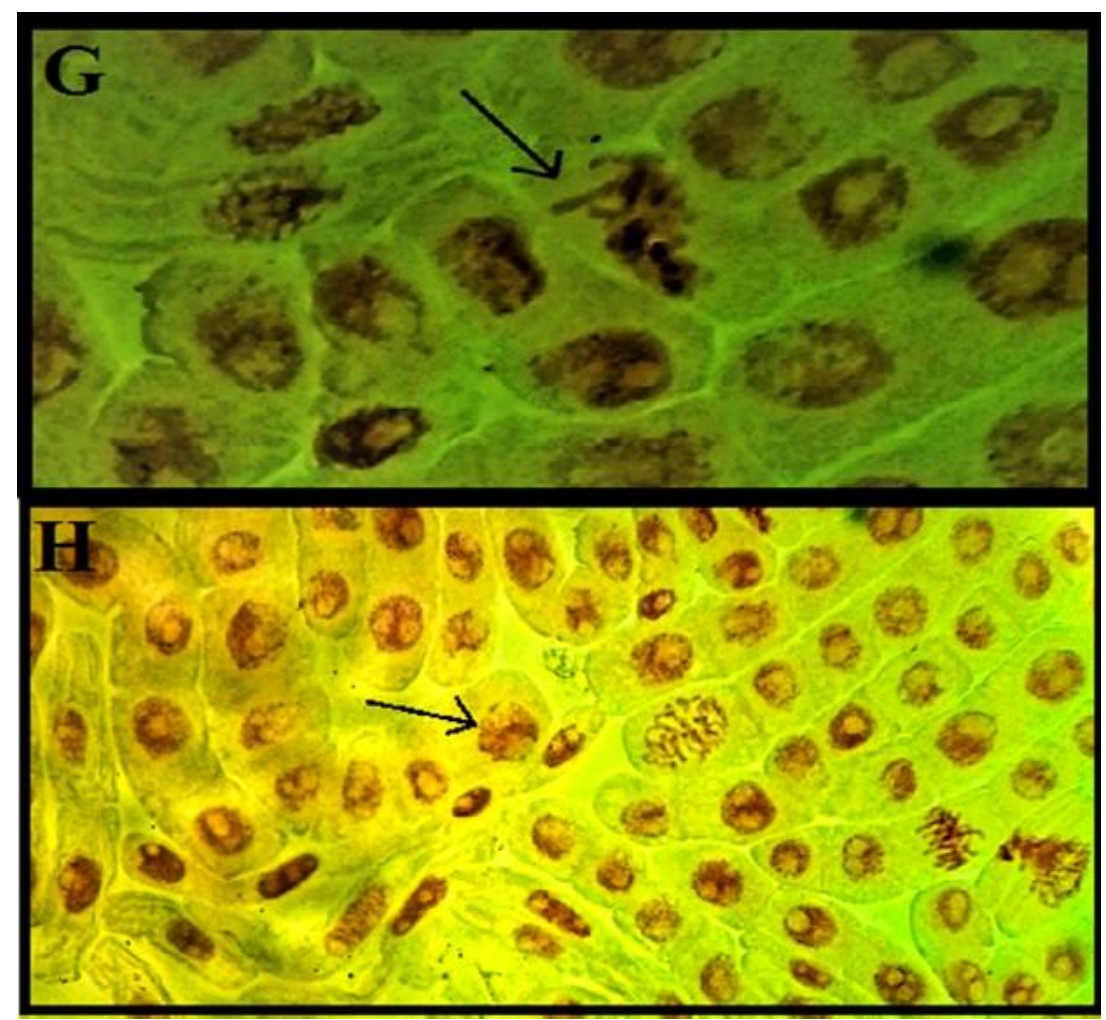

Fig-7: This shows chromosomal aberrations (G) sticky chromosome and (H) nuclear lesion

Table-4: Summary of types and number of chromosomal aberrations in each treatment

\begin{tabular}{|c|c|c|c|c|c|c|c|}
\hline Aberration Variables & $\begin{array}{l}\text { T1-pH of } \\
7.00\end{array}$ & $\begin{array}{l}\text { T2-pH of } \\
3.80\end{array}$ & $\begin{array}{l}\text { T3-pH of } \\
4.08\end{array}$ & $\begin{array}{l}\text { T4- pH of } \\
4.40\end{array}$ & T5- pH of 4.63 & T6- pH of 5.32 & TOTAL \\
\hline Sticky chromosome & 1 & 5 & 7 & 4 & 2 & 4 & 23 \\
\hline Vagrant chromosome & 1 & 9 & 7 & 22 & 7 & 3 & 49 \\
\hline Micronucleus & 0 & 7 & 9 & 20 & 9 & 2 & 47 \\
\hline Laggard chromosome & 0 & 13 & 8 & 5 & 13 & 0 & 39 \\
\hline Bridge & 0 & 29 & 19 & 18 & 6 & 7 & 79 \\
\hline Fragments & 1 & 31 & 12 & 7 & 8 & 4 & 63 \\
\hline Polyploidy & 1 & 16 & 9 & 4 & 6 & 5 & 41 \\
\hline Binucleated & 0 & 16 & 24 & 9 & 10 & 3 & 62 \\
\hline Nuclear lesion & 0 & 54 & 14 & 7 & 8 & 1 & 84 \\
\hline Total & 4 & 180 & 109 & 96 & 69 & 29 & 487 \\
\hline Total Observed cells & 2300 & 2045 & 1751 & 1494 & 1933 & 2020 & \\
\hline
\end{tabular}

\section{CONCLUSION}

This present study revealed that varying $\mathrm{pH}$ values of simulated sulfuric acid rain affects the morphological aspect of root and alter the root cells genetically. Moreover, such findings revealed that more adverse effects were observed when roots were soaked at lower $\mathrm{pH}$ values of simulated sulfuric acid rain. The lower $\mathrm{pH}$ values of the simulated sulfuric acid, the lower number of root counts, lower percentage root growth and accompanied by shorter root length. The lower $\mathrm{pH}$ values of the simulated sulfuric acid rain decreased the prophase, metaphase, anaphase and telophase cell counts significantly, thus, interfered with cell division which resulted to lower mitotic index. The lower $\mathrm{pH}$ values of the simulated sulfuric acid rain caused the chromatin/chromosome reorganization; causing change in either total number of chromosomes or chromosomal structure as indicated by the presence of chromosomal aberrations such as nuclear lesions, chromosomal bridges and fragments, binucleated nucleus, vagrant chromosomes, micronucleus, laggard chromosome, polyploidy and sticky chromosome; hence, chromosomal aberration counts increased as the $\mathrm{pH}$ values of simulated sulfuric acid is decreased. And the lower $\mathrm{pH}$ values of the simulated sulfuric acid rain, increased the occurrence of aberrant cell, hence, higher aberration index was noted. Hence, lower $\mathrm{pH}$ of simulated sulfuric acid rain has genotoxicity action and a potent clastogen.

\section{REFERENCES}

1. Khanna N, Sharma S. Allium cepa root chromosomal aberration assay: a review. Indian Journal of Pharmaceutical and Biological Research. 2013 Sep 30;1(03):105-19.

2. Olorunfemi DI, Ehwre EO. Chromosomal aberrations induced in root tips of Allium cepa by 
Renjith Raju et al., Sch Acad J Biosci, Mar, 2021; 9(3): 89-97

squeezed Garri extracts. Report and Opinion. 2011;2:166-71.

3. Perry L. Extension professor, $\mathrm{pH}$ for Garden, University of Vermont Extension Department of Plant and Soil Science. 2003.

4. Ukaegbu MC, Odeigah PGC. The genotoxic effect of sewage effluent on Allum cepa. 2009.

5. Fiskesjö, G. The Allium-test as a standard in environmental monitoring, Hereditas. 1985;102, pp. 99-112.

6. Fiskesjö G. The Allium test-an alternative in environmental studies: The relative toxicity of metal ions. Mutation Research.1988; 197, 243-260.

7. Fiskesjö G. The Allium test in wastewater monitoring, Environ Toxicology Water Qual. 1993; 8, 291-298.

8. Fiskesjö G. The Allium Test II: Assessment of chemical's genotoxic potential by recording aberrations in chromosomes and cell divisions in root tips of Allium cepa. 1944.

9. Fiskesjö G. Allium test II: Assessment of a chemical's genotoxic potential by recording aberrations in chromosomes and cell divisions in root tips of Allium cepa L. Environmental Toxicology and Water Quality. 1994 Aug;9(3):235-41.

10. Fiskesjö G. Allium test: In vitro toxicity testing protocols. Meth Mol Biol. 1995; 43:119-127.

11. Levan A. The effect of colchicine on root mitoses in Allium. Hereditas. 1938 May;24(4):471-86.

12. Adegbite A, Sanyaolu EB. Cytotoxicity testing of aqueous extract of bitter leaf (Vernonia amygdalina Del.) using the Allium cepa chromosome aberration assay. 2009.
13. Rank J, Nielsen MH. Evaluation of the Allium anaphase-telophase test in relation to genotoxicity screening of industrial wastewater, Mutation Research, 1994; 312.

14. Ma TH. The international program on plant bioassays and the report of the follow-up study after the hands-on workshop in China. Mutation Research/fundamental And Molecular Mechanisms of Mutagenesis. 1999 May 19;426(2):103-6.

15. Bagatini MD, Vasconcelos TG, Laughinghouse H, Martins AF, Tedesco SB. Biomonitoring hospital effluents by the Allium cepa L. test. Bulletin of environmental contamination and toxicology. 2009 May 1;82(5):590.

16. Levan A. The effect of colchicine on root mitoses in Allium, Hereditas, 1938; 24.

17. Love A, Love D. Plant chromosomes.1975.

18. Lubini G, Fachinetto JM, Laughinghouse HD, Paranhos JT, Silva AC, Tedesco SB. Extracts affecting mitotic division in root-tip meristematic cells. Biologia. 2008 Oct;63(5):647-51.

19. Antoniou MG, Cruz AA, \& de la Dionysiou DD. Cyanotoxins: New Generation of Water Contaminants, Journal of Environmental Engineering. 2005; 1239-1243.

20. Çelik TA, Aslantürk OS. Anti-mitotic and anti-genotoxic effects of Plantago lanceolata aqueous extract on Allium cepa root tip meristem cells. 2006.

21. Grover IS, Kaur S. Genotoxicity of wastewater samples from sewage and industrial effluent detected by the Allium root anaphase aberration and micronucleus assays. 1999. 